\title{
Plasma vitamin A and zinc levels in HIV-infected adults in Cape Town, South Africa
}

\author{
M. E. Visser ${ }^{1}$, G. Maartens ${ }^{2}$, G. Kossew and G. D. Hussey ${ }^{3}$ \\ ${ }^{1}$ Nutrition and Dietetics Unit and ${ }^{2}$ Infectious Disease Unit, Department of Medicine and the ${ }^{3}$ Child Health Unit, \\ Department of Paediatrics and Child Health, University of Cape Town, South Africa
}

(Received 18 March 2002 - Revised 18 September 2002 - Accepted 5 November 2002)

\begin{abstract}
A cross-sectional study of 132 adults attending an HIV clinic in Cape Town, South Africa, was conducted to determine predictors of low plasma vitamin A and Zn levels. No patients were on antiretroviral therapy. The possible confounding effect of the acute-phase response was controlled by including C-reactive protein levels in multivariate analysis and by excluding active opportunistic infections. Retinol levels were low $(<1.05 \mu \mathrm{mol} / \mathrm{l})$ in $39 \%$ of patients with early disease (WHO clinical stages I and II) compared with 48 and $79 \%$ of patients with WHO stage III and IV respectively $(P<0.01)$. Plasma Zn levels were low $(<10.7 \mu \mathrm{mol} / \mathrm{l})$ in $20 \%$ of patients with early disease $v .36$ and $45 \%$ with stage III and IV disease respectively $(P<0 \cdot 05)$. C-reactive protein levels were normal in $63 \%$ of subjects. Weak, positive associations were found between CD4+ lymphocyte count and plasma levels of retinol $(r 0 \cdot 27 ; 95 \%$ CI $0 \cdot 1$, $0.43)$ and $\mathrm{Zn}(r 0.31 ; 95 \% \mathrm{CI} 0.25,0.46)$. Multivariate analysis showed the following independent predictors of low retinol levels: WHO stage IV (odds ratio $3 \cdot 4 ; 95 \%$ CI $2 \cdot 1,5 \cdot 7$ ) and body weight (odds ratio per $5 \mathrm{~kg}$ decrease $1.15 ; 95 \% \mathrm{CI}, 1.08,1 \cdot 25$ ), while only body weight was significantly associated with low $\mathrm{Zn}$ levels (OR per $5 \mathrm{~kg}$ decrease $1.19 ; 95 \%$ CI 1.09, 1.30). CD4+ lymphocyte count $<200 / \mu$ l was not significantly associated with either low retinol or $\mathrm{Zn}$ levels. In resource-poor settings, simple clinical features (advanced disease and/or weight loss) are associated with lowered blood concentrations of vitamin A and/or $\mathrm{Zn}$. The clinical significance of low plasma retinol and/or $\mathrm{Zn}$ levels is unclear and more research is required to establish the role of multiple micronutrient intervention strategies in HIV disease.
\end{abstract}

HIV infection: Vitamin A: Zinc: C-Reactive Protein: Africa

HIV infection continues to increase worldwide, and an estimated 28.5 million adults and children are infected in sub-Saharan Africa alone (Joint United Nations Programme on HIV/AIDS (UNAIDS) 2002). Most studies investigating the micronutrient status of HIV-infected populations have reported low serum or plasma levels of micronutrients such as vitamins $\mathrm{A}, \mathrm{E}, \mathrm{B}_{6}, \mathrm{~B}_{12}, \mathrm{C}$ and carotenoids, as well as trace elements such as $\mathrm{Zn}$ and Se. However, limited results exist for developing countries (Semba \& Tang, 1999).

Vitamin A plays a central role in the growth and function of $\mathrm{T}$ and $\mathrm{B}$ cells, antibody responses and maintenance of mucosal epithelia (Semba, 1994). Low blood levels of vitamin A are associated with accelerated disease progression and increased mortality in HIV-infected adults (Semba et al. 1993, 1995; Baum et al. 1995, 1997; Tang et al. 1997). In addition, low concentrations of vitamin A may be associated with increased mother-tochild transmission of HIV, higher infant mortality and child growth failure (Semba et al. 1994, 1997a,b; Greenberg et al. 1997).

In Africa, low blood vitamin A concentrations $(<1.05 \mu \mathrm{mol} / \mathrm{l})$ have been reported in $50-63 \%$ of HIVinfected pregnant women (Semba, 1997; Moodley et al. 1998). Approximately one-third of seropositive adults attending an outpatient clinic in Uganda, had lowered serum vitamin A levels (Semba, 1997). Another study, conducted among in-patients co-infected with tuberculosis in Rwanda, showed that $29 \%$ of patients presented with low blood vitamin A levels (Rwangabwoba et al. 1998). A recent clinical trial among HIV-infected adults with persistent diarrhoea showed that $63 \%$ of patients had vitamin A concentrations consistent with a deficiency state $(<0.7 \mu \mathrm{mol} / \mathrm{l})$ (Kelly et al. 1999).

\footnotetext{
Abbreviations: CRP, C-reactive protein; IQR, interquartile range.

*Corresponding author: Ms Marianne Visser, fax +27 21 4066534, email mvisser@uctgsh1.uct.ac.za
} 
$\mathrm{Zn}$ is essential for the maturation and differentiation of $\mathrm{T}$ lymphocytes and the functioning of cells mediating nonspecific immunity such as neutrophils and natural killer cells (Shankar \& Prasad, 1998). According to a recent review, no results have yet been reported regarding the prevalence of $\mathrm{Zn}$ deficiency, as measured by plasma levels, in HIV-infected patients in Africa (Piwoz \& Preble, 2000). However, low Zn levels $(<10.7 \mu \mathrm{mol} / \mathrm{l})$ have previously been reported in $25-29 \%$ of HIV-infected adults in the USA (Beach et al. 1992; Koch et al. 1996; Baum et al. 1997). Such low concentrations of $\mathrm{Zn}$ have been shown to be predictive of HIV disease progression and mortality (Graham et al. 1991; Baum et al. 1997).

In a search for more cost-effective interventions to reduce morbidity and mortality in HIV-disease, the identification and correction of micronutrient deficiencies such as vitamin $\mathrm{A}$ and $\mathrm{Zn}$, may take on increasing importance. A crosssectional study was therefore conducted to determine the plasma vitamin $\mathrm{A}$ and $\mathrm{Zn}$ levels of HIV-infected adults in South Africa and to investigate their relationships with clinical stage, controlling for the acute-phase response.

\section{Methods}

The study population consisted of a sample of HIVinfected adults who attended the Groote Schuur Hospital (Cape Town) outpatient clinic consecutively between October 1995 and October 1996 and in whom routine blood tests were requested by the attending medical practitioner. HIV-seropositivity was confirmed according to the WHO antibody-testing strategy, namely by means of three positive enzyme immunoassays (Martin et al. 1995a). Exclusion criteria included anti-retroviral therapy, current use of vitamin supplements, pregnancy and a clinical diagnosis of liver disease. Patients with pyrexia $\left(>38^{\circ} \mathrm{C}\right)$, those who were receiving treatment for an acute opportunistic infection, as well as patients on therapy for tuberculosis for $<12$ weeks, were also excluded. The study was approved by the Research and Ethics Committee at the University of Cape Town.

After written informed consent was obtained, subjects were interviewed to obtain socio-demographic information such as educational level, current employment, type of housing and the availability of electricity or a refrigerator. The clinical stage of each patient was assessed by a medical practitioner according to the WHO clinical staging system (World Health Organization International Collaborating Group for the the Study of the World Health Organization Staging System, 1993). Body weight was measured to the nearest $0.1 \mathrm{~kg}$ with a beam-balance scale, which was calibrated at monthly intervals. Subjects were required to remove heavy clothing and shoes. Height was determined with a stadiometer to the nearest $1 \mathrm{~mm}$. BMI $\left(\mathrm{kg} / \mathrm{m}^{2}\right)$ was calculated for each subject.

Venous blood for the determination of plasma retinol, $\mathrm{Zn}$ and C-reactive protein (CRP) was collected between $13 \cdot 30$ and 15.30 hours and subjects were therefore in a fed state. The puncture site was cleaned with trace-element free alcohol to avoid contamination. All specimens were promptly transported to the laboratory, protected from light and stored at $-20^{\circ} \mathrm{C}$ after centrifugation, until analysis.
Plasma retinol levels were determined by the fluorometric method (Underwood, 1990a,b). Duplicate retinol (Sigma Co., Johannesburgh, South Africa) reference standards were prepared in ethanol for the spectrofluorophotometer (E\% value: 1835 at $325 \mathrm{~nm}$ ) for each batch of specimens. Plasma CRP levels were determined by nephelometry using an international reference standard for plasma proteins (Behringwerke AG, Marburg, Germany). CRP levels $\geq 10 \mathrm{mg} / \mathrm{l}$ were considered to be elevated. Plasma levels of $\mathrm{Zn}$ were measured by atomic absorption spectrophotometry (Tietzman, 1987). CD4+ and CD8+ T lymphocyte counts were measured by a Coulter flow cytometer (EPICS Profile II, FL, USA).

We estimated that approximately $30 \%$ of our study population had low plasma retinol levels. To estimate such a proportion with a precision of $7.5 \%, 143$ patients were needed. Clinic records showed that patient attendance was evenly distributed across clinical strata. Assuming a difference between strata proportions of $\leq 10 \%$, this would lead to a $\chi^{2}$ test for trend with significance $<5 \%$.

\section{Statistical analysis}

Statistical analysis was performed using Epi-info (version 6; CDC, Atlanta, GA, USA) and SAS Statistical package, (version 6.03; SAS Institute Inc., Cary, NC, USA). Continuous variables were assessed across clinical stage categories by the Kruskal-Wallis test due to the non-normality of the data. Differences in continuous variables between male and female subjects were assessed by the Wilcoxon ranksum test. The relationship between categorical variables and clinical stage was assessed by the $\chi^{2}$ test for trend. Univariate associations between continuous variables were performed using the Spearman correlation coefficient. Multivariate logistic regression was performed using a stepwise approach, with plasma retinol $(<1.05 \mu \mathrm{mol} / \mathrm{l})$ and $\mathrm{Zn}(<10.7 \mu \mathrm{mol} / \mathrm{l})$ as binary outcome variables. Independent variables such as clinical stage, body weight, CD4+ cell count, haemoglobin, packed cell volume and CRP levels were examined. The presence of colinearity $(r \geq 0.8)$ was assessed in order to prevent the inclusion of strongly correlated variables into the multivariate models.

\section{Results}

A total number of $247 \mathrm{HIV}$-infected patients attended the clinic during the specified time period; however, routine blood tests were not requested in thirty-eight patients. Furthermore, seventy-six patients were also excluded according to the following criteria: $<18$ years old $(n 1)$; the presence of active opportunistic infection at the time of the clinic visit ( $n$ 10); on current drug therapy for tuberculosis for $<12$ weeks ( $n$ 32); clinical diagnosis of liver disease ( $n 3)$; use of multivitamin supplements at the time or during the preceding 6 months ( $n$ 17); pregnancy ( $n$ 9); prisoners $(n 1)$; problems with venous access $(n 3)$. One patient refused to participate in the study. None of our subjects were receiving anti-retroviral therapy at the time or prior to study enrolment.

Results are therefore presented on a total number of 132 patients (Table 1). It has previously been demonstrated 
that patients with WHO stage I and II HIV infection display similar survival curves (Post et al. 1996). Therefore, these patients were grouped together during data analysis, representing early HIV disease. The initial AIDS-defining illness of stage IV patients and the time period between the latter and study enrolment, is listed in Table 2. The mode of transmission for all subjects was heterosexual. No differences were noted between subjects in the different clinical stage categories in terms of the different demographic variables measured. However, only 13 and $14 \%$ of subjects with stage III and IV disease respectively, were employed at the time of the study, compared with $43 \%$ of subjects with early disease $(P<0.05)$.

Table 1 shows that the number of patients with low plasma levels of retinol $(<1.05 \mu \mathrm{mol} / \mathrm{l})$ (Pilch, 1987) and $\mathrm{Zn}(<10.7 \mu \mathrm{mol} / \mathrm{l})$ (Tietzman, 1987), was significantly $(P<0.001$ and $P<0.01$ respectively) higher among those with stage III and IV disease, compared with patients with early disease. The median retinol level for patients with early disease was 1.19 (interquartile range (IQR) 0.85-1.50) $\mu \mathrm{mol} / \mathrm{l}$, compared with 1.07 (IQR 0.86-1.32) and 0.83 (IQR $0.59-0.99) \mu \mathrm{mol} / \mathrm{l}$ for those with stage III and IV disease, respectively $(P<0 \cdot 01)$. In terms of plasma $\mathrm{Zn}$, the median level for patients with early disease was 12.9 (IQR 11.0-15.3) $\mu \mathrm{mol} / \mathrm{l}$, compared with $11.9 \mu \mathrm{mol} / \mathrm{l}$ (IQR 9.8-14.1) and 11.0 (IQR 9.2-13.8) $\mu \mathrm{mol} / \mathrm{l}$ for those with stage III and IV disease respectively $(P<0.01)$

The median body weight for patients with early disease was 66.0 (IQR 56.5-78.0) kg, compared with 60.5 (IQR $55 \cdot 0-66.1) \mathrm{kg}$ and 58.0 (IQR $46 \cdot 0-65.7$ ) $\mathrm{kg}$ for those with stage III and IV disease respectively $(P<0.02)$.
No sex differences in terms of body weight within the three clinical staging categories were demonstrated. Due to incompleteness of data, BMI was determined in 116 patients. Only seven of twenty-nine patients with stage IV disease had a BMI $<18.5 \mathrm{~kg} / \mathrm{m}^{2}$ and could therefore be categorised as having chronic energy deficiency (James et al. 1988) (Table 1).

The majority of our patients did not have elevated plasma CRP levels $(\geq 10 \mathrm{mg} / \mathrm{l})$, although a significant difference was noted across clinical stage categories (Table 1). Only one patient with stage III disease presented with a CRP level $>100 \mathrm{mg} / \mathrm{l}$. This observation was not excluded.

We demonstrated weak, positive associations between CD4+ lymphocyte levels and plasma levels of retinol $(r$ $0.27 ; 95 \%$ CI $0.10,0.43)$ and $\mathrm{Zn}(r 0.31 ; 95 \%$ CI 0.25 , $0 \cdot 46$ ), using the Spearman correlation coefficient. Similar associations were noted between the CD4+: CD8+ lymphocyte ratio and plasma retinol and $\mathrm{Zn}$ levels.

Multivariate analysis demonstrated that stage IV disease was independently associated with a threefold increased risk of low plasma retinol levels $(<1.05 \mu \mathrm{mol} / \mathrm{l})$ after adjusting for CD4+ lymphocyte count, haemoglobin levels and body weight (Table 3). Low haemoglobin levels $(<120 \mathrm{~g} / \mathrm{l})$ and a decrease in body weight were both independent predictors of low retinol levels. The CD4+ lymphocyte count $(<200 \quad$ cells/ $\mu \mathrm{l})$ and CD4+ : CD8+ lymphocyte ratio $(<0 \cdot 15)$ were only significantly associated during univariate analysis. Plasma $\mathrm{Zn}$ and CRP levels did not contribute significantly to the model, nor did it change the adjusted odds ratios of any of the covariates.

Table 1. Characteristics of HIV-infected adults according to World Health Organization clinical staging of HIV-infection*

\begin{tabular}{|c|c|c|c|c|c|c|c|}
\hline & \multicolumn{2}{|c|}{$\begin{array}{l}\text { WHO stage I } \\
\text { and II }\end{array}$} & \multicolumn{2}{|c|}{ WHO stage III } & \multicolumn{2}{|c|}{ WHO stage IV } & \multirow{2}{*}{$\begin{array}{c}\text { Statistical significance } \\
\text { of effect: } P\end{array}$} \\
\hline & $n$ & $\%$ & $n$ & $\%$ & $n$ & $\%$ & \\
\hline \multicolumn{8}{|l|}{ Age (years) } \\
\hline$<30$ & 21 & 41 & 22 & 46 & 16 & 49 & \\
\hline$\geq 30$ & 30 & 59 & 26 & 54 & 17 & 51 & \\
\hline \multicolumn{8}{|l|}{ Sex } \\
\hline Male & 15 & 29 & 17 & 35 & 15 & 45 & \\
\hline Female & 36 & 71 & 31 & 65 & 18 & 55 & \\
\hline \multicolumn{8}{|c|}{ CD4+ lymphocyte count (cells/ $\mu$ l) } \\
\hline$<200$ & 9 & 19 & 26 & 55 & 22 & 69 & 0.001 \\
\hline$\geq 200$ & 38 & 81 & 21 & 45 & 10 & 31 & \\
\hline \multicolumn{8}{|l|}{ BMI } \\
\hline$<18.5$ & 2 & 4 & 3 & 7 & 7 & 24 & 0.01 \\
\hline $18.5-24.9$ & 22 & 49 & 28 & 66 & 14 & 48 & \\
\hline$\geq 25$ & 21 & 47 & 11 & 27 & 8 & 28 & \\
\hline \multicolumn{8}{|c|}{ Plasma C-reactive protein (mg/l) } \\
\hline$<10$ & 39 & 77 & 25 & 52 & 19 & 58 & 0.05 \\
\hline $10-40$ & 11 & 23 & 19 & 40 & 12 & 36 & \\
\hline$>40$ & 1 & 2 & 4 & 8 & 2 & 6 & \\
\hline \multicolumn{8}{|c|}{ Plasma retinol $(\mu \mathrm{mol} / \mathrm{l})$} \\
\hline$<1.05$ & 20 & 39 & 23 & 48 & 26 & 79 & 0.001 \\
\hline$\geq 1.05$ & 31 & 61 & 25 & 52 & 7 & 21 & \\
\hline \multicolumn{8}{|c|}{ Plasma zinc $(\mu \mathrm{mol} / \mathrm{l})$} \\
\hline$<10 \cdot 7$ & 10 & 20 & 17 & 36 & 15 & 45 & 0.01 \\
\hline$\geq 10.7$ & 40 & 80 & 30 & 64 & 16 & 55 & \\
\hline
\end{tabular}

* For details of classification, see World Health Organization International Collaborating Group for the study of the World Health Organization Staging System (1993). 
Table 2. Initial AIDS-defining illnesses of World Health Organization clinical stage IV patients ${ }^{\star} \dagger$ (Mean values and standard deviations for twenty-three subjects)

\begin{tabular}{lrcr}
\hline AIDS-defining illness & $n$ & $\begin{array}{c}\text { Time period between AIDS-defining } \\
\text { illness and study enrolment (months) }\end{array}$ & SD \\
\hline Extrapulmonary tuberculosis & 20 & 11.2 & 10.7 \\
Pneumocystis carinii pneumonia & 2 & 3.0 & 1.4 \\
Cryptococcosis & 1 & 3.0 & \\
Toxoplasmosis & 1 & 1.0 & \\
Herpes simplex virus & 1 & 0.0 & 10.2 \\
Kaposi's sarcoma & 3 & 7.3 & 2.9 \\
Oesophageal candidiasis & 3 & 1.7 & \\
HIV-wasting syndrome & 2 & 0.0 &
\end{tabular}

${ }^{*}$ For details of subjects, see Table 1.

†For details of classification, see World Health Organization International Collaborating Group for the study of the World Health Organization Staging System (1993).

Table 4 demonstrates that a decrease in body weight was the only significant independent predictor of low plasma $\mathrm{Zn}$ levels. During univariate analysis, stage IV disease and a low CD4+ lymphocyte count $(<200$ cells $/ \mu l)$, were almost significant. As earlier, the inclusion of CRP levels did not contribute significantly to the model.

\section{Discussion}

The overall prevalence of low plasma retinol concentrations in our study population was $52 \%$, which is comparable with results among infected adults from developing countries (Semba, 1997; Rwangabwoba et al. 1998). To our knowledge, this is the first study reporting the prevalence of low plasma $\mathrm{Zn}$ levels among HIV-infected adults in Africa. Although the proportion of asymptomatic patients who presented with low blood $\mathrm{Zn}$ levels was comparable with previously reported results, a significantly larger number of patients with advanced disease were deficient in $\mathrm{Zn}(P<0 \cdot 05)$. A limitation of the present study is that plasma levels of vitamin $\mathrm{A}$ and $\mathrm{Zn}$ were not measured in sero-negative individuals. However, Kafwembe et al. (2001) demonstrated that HIV-infected individuals in Zambia were 6.3-times more likely to present with low vitamin A concentrations, when compared with sero-negative individuals.

It is likely that several factors contributed to the development of micronutrient deficiencies, such as vitamin A and $\mathrm{Zn}$, in our present study population. Patients with advanced disease were more likely to be unemployed and therefore, although we did not assess the dietary intake of vitamin A and $\mathrm{Zn}$, it is likely that socio-economic factors contributed to a poorer micronutrient intake in those patients. Rwangabwoba et al. (1998) demonstrated that among a group of HIV-infected patients who were co-infected with tuberculosis, patients who presented with weight loss had significantly lower vitamin A levels. Only a small number of our patients were suffering from chronic energy deficiency $\left(\mathrm{BMI}<18.5 \mathrm{~kg} / \mathrm{m}^{2}\right)$ at study entry. However, multivariate analysis demonstrated that a higher body weight has a significant protective effect in terms of the development of a deficiency in vitamin A and Zn (Tables 3 and 4).

Although we excluded patients with active infections at the time of study entry, it is likely that previous episodes of infection may have contributed to the depletion of micronutrient stores, such as retinol (Semba, 1997). During infections, plasma retinol levels may decrease due to a poor food intake, an increased utilisation of retinol by target tissues or via increased urinary losses of vitamin A (Campos et al. 1987; Stephenson et al. 1994). In addition, serum concentrations of several nutrients decline during the acute-phase response, either because they are re-distributed in the body or because they are bound to acute-phase proteins. The precise effect of the acute-phase response on the metabolism of vitamin A is unclear, but it is well documented that infections result in lowered serum retinol levels and hepatic vitamin A stores. During the acutephase response, plasma $\mathrm{Zn}$ and Fe levels also decrease due to hepatic sequestration, whereas $\mathrm{Cu}$ levels increase due to an increase in caeruloplasmin. Decreased retinol levels may be caused by a reduced mobilisation of retinol-binding protein from the liver due to hypozincaemia, since retinol-binding protein is a $\mathrm{Zn}$-dependent protein (Fleck, 1989; Raynes, 1994). The serum micronutrient

Table 3. Predictors of plasma retinol levels $<1.05 \mu \mathrm{mol} / /$ in HIV-infected adults* (Unadjusted and adjusted odds ratios and $95 \%$ confidence intervals)

\begin{tabular}{|c|c|c|c|c|}
\hline Variable & $\mathrm{OR}_{\text {Unadjusted }}$ & $95 \% \mathrm{Cl}$ & $\mathrm{OR}_{\text {Adjusted }}$ & $95 \% \mathrm{Cl}$ \\
\hline WHO clinical stage IV† & $4 \cdot 8$ & $3 \cdot 0,7 \cdot 6$ & $3 \cdot 4$ & $2 \cdot 1,5 \cdot 7$ \\
\hline CD4+ count $<200$ cells $/ \mu$ l & $3 \cdot 6$ & $2 \cdot 4,5 \cdot 6$ & 1.4 & $0 \cdot 9,2 \cdot 1$ \\
\hline Haemoglobin < $120 \mathrm{~g} / \mathrm{l}$ & $3 \cdot 3$ & $2 \cdot 3,4 \cdot 8$ & $2 \cdot 4$ & $1 \cdot 6,3.5$ \\
\hline Body weight (per $5 \mathrm{~kg}$ decrease) & $1 \cdot 22$ & $1 \cdot 02,1.30$ & $1 \cdot 15$ & $1.08,1.25$ \\
\hline
\end{tabular}

OR, odds ratio

${ }^{*}$ For details of subjects and procedures, see Tables 1 and 2

†For details of classification, see World Health Organization International Collaborating Group for the study of the World Health Organization Staging Sysem (1993). 
Table 4. Predictors of plasma zinc levels $<10.7 \mu \mathrm{mol} / \mathrm{I}$ in HIV-infected adults ${ }^{*}$ (Unadjusted and adjusted odds ratios and $95 \%$ confidence intervals)

\begin{tabular}{lcccc}
\hline Variable & OR $_{\text {Unadjusted }}$ & $95 \% \mathrm{Cl}$ & OR $_{\text {Adjusted }}$ & $95 \% \mathrm{Cl}$ \\
\hline WHO clinical stage IV† & 2.2 & $0.94,4.90$ & 2.2 & $0.9,6.0$ \\
CD4+ count $<200 \mathrm{cells} / \mu \mathrm{l}$ & 2.2 & $1.0,4.8$ & 1.4 & $0.6,3.2$ \\
Body weight (per 5 kg decrease) & 1.19 & $1 \cdot 10,1.28$ & 1.19 & $1.09,1.30$ \\
\hline
\end{tabular}

OR, odds ratio.

* For details of subjects and procedures, see Tables 1 and 2 .

†For details of classification, see World Health Organization International Collaborating Group for the Study of the World Health Organization Staging System (1993).

status of HIV-infected individuals with acute infections should therefore always be interpreted with caution due to potential misclassification (Fawzi \& Hunter, 1998).

In our present study, CRP was measured as a marker of the acute-phase response. CRP is a non-specific marker of inflammation or infection and very high plasma CRP concentrations $(>100 \mathrm{mg} / \mathrm{l})$ are more likely to be associated with bacterial than viral infections (Young et al. 1991). Interleukin 6 is thought to be the main mediator of CRP production (Castell et al. 1990). HIV-infection per se is known to stimulate macrophages resulting in increased interleukin 6 levels, even in asymptomatic HIV-positive patients (Breen et al. 1990). It has been suggested that interleukin 6 levels increase with the progression of HIVinfection (Honda et al. 1990). In our present study, a significant number of patients with advanced disease had mildly elevated plasma CRP levels $(10-40 \mathrm{mg} / \mathrm{l})$, which may be attributable to a direct effect of HIV stage I activity (Table 1). This is consistent with the findings of Tang et al. (1997) who showed that $55 \%$ of their HIV-infected cohort, of whom $81 \%$ were asymptomatic, had elevated serum CRP levels ( $\geq 8 \mathrm{mg} / \mathrm{l})$. Melchior et al. (1999) recently demonstrated that CRP was an independent predictor of survival in a group of HIV-infected patients, who were free of opportunistic infections at the time of study entry. They suggested that elevated CRP concentrations may be related to the rate of virus replication; however, they did not measure viral load. Serum retinol levels are negatively associated with elevated CRP levels in adults undergoing orthopaedic surgery and in schoolchildren with schistosomiasis (Louw et al. 1992; Friis et al. 1996). It has been suggested that low plasma $\mathrm{Zn}$ levels are reflective of the acute-phase response due to HIV-viral activity (Graham et al. 1991). However, multivariate analysis demonstrated that CRP was not an independent predictor of low levels of vitamin $\mathrm{A}$ or $\mathrm{Zn}$ in our present study.

Lower CD4+ cell counts are associated with low retinol levels among HIV-infected individuals, while the normalisation of retinol and $\mathrm{Zn}$ levels have been associated with higher counts (Semba et al. 1993; Baum et al. 1995). Our present findings confirmed weak, positive associations between CD4+ lymphocyte counts and plasma levels of retinol and $\mathrm{Zn}$. The potential confounding effect of tuberculosis on CD4+ counts was controlled for by restricting our present sample to patients who had received drug treatment for at least 12 weeks. A significant rise in CD4+ counts after that period of time has been demonstrated (Martin et al. $1995 b$ ). Retinoids are known to enhance cellular differentiation of haemopoietic cells and the lineage of other cells
(Nuget \& Clark, 1985). Thus, retinol status may be important for the differentiation of CD4+ cells. In human subjects, $\mathrm{Zn}$ deficiency results in rapid and marked atrophy of the thymus, lymphopaenia and a reduction of primary and secondary antibody responses, particularly for those antigens that require T cell help (Shankar \& Prasad, 1998).

Our present findings demonstrate that patients with WHO stage IV disease had a threefold risk of having plasma retinol levels $<1.05 \mu \mathrm{mol} / \mathrm{l}$, after adjusting for CD4+ lymphocyte count, body weight and haemoglobin levels (Table 3). On the other hand, a decrease in body weight was the only significant predictor of low $\mathrm{Zn}$ levels in our present study (Table 4). CD4+ lymphocyte count and the CD4+:CD8+ lymphocyte ratio were not independent predictors of a low retinol status in the present study, after adjusting for clinical stage. Reduced haemoglobin and packed cell volume levels have been associated with low serum retinol levels in HIV-infected patients (Semba et al. 1993, 1995). Haemoglobin may be an intermediate variable in the relationship between vitamin A and AIDS, since haematopoiesis is vitamin A-dependent. It appears that vitamin A-deficient children are prone to the development of a mild Fe-deficiency anaemia and that vitamin A supplementation may improve haematopoiesis in children who are vitamin A deficient. Vitamin A may therefore be involved in the regulation of $\mathrm{Fe}$ release from hepatic stores (Meijia \& Chew, 1988; Semba et al. 1992).

CD4+ lymphocyte counts are a standard laboratory marker of disease progression in HIV infection, but expense precludes their use in many resource-poor settings in Africa. We demonstrated that WHO clinical stage IV HIV disease was a stronger predictor of low plasma concentrations of micronutrients, such as vitamin A, than CD4+ cell counts in our present study population. It could thus be argued that these patients might be targeted for micronutrient supplementation by practitioners at a primary-care level. However, it must be noted that our crosssectional study design precludes any causal inferences about the association between plasma vitamin $\mathrm{A}$ and $\mathrm{Zn}$ status and the progression of HIV disease.

High-dose vitamin A supplementation has been shown to reduce diarrhoeal disease morbidity and AIDS-related mortality in HIV-infected children, and improve the CD4+ cell counts of children with AIDS (Coutsoudis et al. 1995; Hussey et al. 1996; Fawzi et al. 1999). In contrast, the short-term administration of high doses of vitamin A in HIV-infected adults did not increase CD4+ counts. The HIV viral load remained unchanged. However, only a small number of adults in two of the three studies cited 
had plasma vitamin A levels that were consistent with deficiency (Coutsoudis, 1997; Semba et al. 1998; Humphrey et al. 1999). High circulating HIV viral load has been shown to be a risk factor for HIV progression (Ferre et al. 1995). It has been suggested that vitamin A deficiency and viral load may be independent risk factors for the progression of HIV disease (Semba, 1997). Several clinical trials have documented the lack of a beneficial effect of vitamin A supplementation on reducing the mother-to-child transmission of HIV. In view of these findings, it has been suggested that serum retinol concentrations may be merely markers of HIV-disease severity, which is an important predictor of vertical transmission (Semba, 1997; Coutsoudis et al. 1999; Fawzi et al. 2000). However, other potential biological mechanisms still remain, whereby vitamin A supplementation may be beneficial in reducing morbidity and mortality in HIV disease.

$\mathrm{Zn}$ supplementation has been demonstrated to increase the efficiency of the immune system in a number of study populations, including marasmic infants (Castillo-Duran et al. 1987), and children recovering from malnutrition (Golden \& Golden, 1981). A recent meta-analysis showed that $\mathrm{Zn}$ has a major role to play in the primary prevention of diarrhoeal disease and acute lower respiratory tract infections in children from developing countries. (Zinc Investigators' Collaborative Group, 1999). Few Zn supplementation studies have been conducted in HIV-AIDS patients. Supplementation for 1 month of adults with AIDS on zidovudine therapy resulted in the stabilisation of body weight, as well as increases in CD4+ cell count and plasma levels of $\mathrm{Zn}$-bound thymulin. A marked reduction in opportunistic infections in the $\mathrm{Zn}$-treated group was also demonstrated (Mocchegiani et al. 1995).

\section{Conclusion}

Our present findings suggest that low plasma concentrations of vitamin $\mathrm{A}$ and $\mathrm{Zn}$ are common among HIV-infected adults attending an outpatient health facility in South Africa. We showed that patients with advanced disease and/or weight loss were more likely to present with low plasma levels, even in the absence of any opportunistic infection, especially in the case of plasma retinol levels.

At present, it is not known whether low serum or plasma levels merely reflect disease progression or whether they indicate true micronutrient deficiencies. Clinical trials are needed to evaluate the safety and effectiveness of micronutrient supplements such as vitamin $\mathrm{A}$ and $\mathrm{Zn}$ on the progression of HIV disease in developing countries, where the majority of HIV-infected individuals are likely to have a marginal micronutrient status. In sub-Saharan Africa, where antiretroviral therapies are prohibitively expensive, the optimisation of micronutrient status may be among the affordable strategies available to improve the morbidity and mortality of HIV-infected adults and children.

\section{Acknowledgements}

We wish to thank the nursing staff at the Groote Schuur outpatient clinic for their assistance with data collection for this study, as well as Ms Fransesca Little and Mr Motasim Badri for their advice and assistance with statistical analysis.

\section{References}

Baum MK, Shor-Posner G, Lu Y, Rosner B, Sauberlich HE, Fletcher MA, Szapocznik J, Eisdorfer C, Buring JE \& Hennekens CH (1995) Micronutrients and HIV-1 disease progression. AIDS 9, 1051-1056.

Baum MK, Shor-Posner G, Lai S, Zhang G, Lai H, Zhang G, Lai H, Fletcher M, Sauberlich H \& Page JB (1997) High risk of HIV-related mortality is associated with selenium deficiency. Journal of Acquired Immune Deficiency Syndromes and Human Retrovirology 15, 370-374.

Beach RS, Mantero-Atienza E, Shor-Posner G, Javier JJ, Szapocznik J, Morgan R, Sauberlich HE, Cornwell PE, Eisdorfer C \& Baum MK (1992) Specific nutrient abnormalities in asymptomatic HIV-1 infection. AIDS 6, 701-708.

Breen EC, Rezai AR, Nakajima K, Beall GN, Mitsuyasu RT, Hirano T, Kishimoto T \& Matinez-Maza O (1990) Infection with HIV is associated with elevated IL-6 levels and production. Journal of Immunology 144, 480-484.

Campos FACS, Flores H \& Underwood B (1987) Effect of an infection on vitamin A status of children as measured by the relative dose response (RDR). American Journal of Clinical Nutrition 46, 91-94.

Castell JV, Goméz-Lechón MJ, David M, Fabra R, Trullenque R \& Heinrich PC (1990) Acute-phase response of human hepatocytes: regulation of acute-phase protein synthesis by interleukin-6. Hepatology 12, 1179-1186.

Castillo-Duran C, Heresi G, Fisberg M \& Uauy R (1987) Controlled trial of zinc supplementation during recovery from malnutrition: effects on growth and immune function. American Journal of Clinical Nutrition 45, 602-608.

Coutsoudis A (1997) Effects of vitamin A supplementation on viral load in HIV-1 infected pregnant women. Journal of the Acquired Immune Deficiency Syndromes and Human Retrovirology 15, 86.

Coutsoudis A, Bobat R, Coovadia H, Huhn L, Tsai W \& Stein Z (1995) The effects of vitamin A supplementation on the morbidity of children born to HIV-infected women. American Journal of Public Health 85, 1076-1081.

Coutsoudis A, Pillay K, Spooner E, Kuhn L \& Coovadia HM (1999) Randomized trial testing the effect of vitamin A supplementation on pregnancy outcomes and early mother-tochild transmission in Durban, South Africa. AIDS 13, 1517-1524.

Fawzi WW \& Hunter DJ (1998) Vitamins in HIV disease progression and vertical transmission. Epidemiology 9, 457-466.

Fawzi W, Mbise R, Hertzmark E, Fataki M, Herrera M, Ndossi G \& Spiegelman D (1999) A randomized trial of vitamin A suppplements in relation to mortality among HIV-infected and uninfected children in Tanzania. Pediatric Infectious Diseases Journal 18, 127-133.

Fawzi WW, Msamanga G, Hunter D, Urassa E, Renjifo B, Mwakagile D, Hertzmark E, Coley J, Garland M, Kapiga S, Antelman G, Essex M \& Spiegelman D (2000) Randomized trial of vitamin supplements in relation to vertical transmission of HIV-1 in Tanzania. Journal of Acquired Immune Deficiency Syndromes 23, 246-254.

Ferre F, Moss RB, Daigle A, Richieri SP, Jensen F \& Carlo DJ (1995) Viral load in peripheral blood mononuclear cells as surrogate for clinical progression. Journal of Acquired Immune Deficiency Syndromes 10, Suppl., 51-56. 
Fleck A (1989) Clinical and nutritional aspects of changes in acute-phase proteins during inflammation. Proceedings of the Nutrition Society 48, 347-354.

Friis H, Ndhlovu P, Kaondera K, Sandstrom B, Michaelsen KF \& Vennervald BJ (1996) Serum concentration of micronutrients in relation to schistosomiasis and indicators of infection: a cross-sectional study amongst rural Zimbabwean schoolchildren. European Journal of Clinical Nutrition 50, 386-391.

Golden MH \& Golden BE (1981) Effect of zinc supplementation on the dietary intake, rate of weight gain, and energy cost of tissue deposition in children recovering from severe malnutrition. American Journal of Clinical Nutrition 34, 900-908.

Graham N, Sorenson D, Odaka N, Brookmeyer R, Chan D, Willett W, Morris JS \& Saah AJ (1991) Relationship of serum copper and zinc levels to HIV-1 seropositivity and progression to AIDS. Journal of Acquired Immune Deficiency Syndromes 4, 976-980.

Greenberg BL, Semba RD, Vink PE, Farley J, Sivapalasingam M, Steketee RW, Thea DM \& Schoenbaum EE (1997) Vitamin A deficiency and maternal-infant transmission of HIV in two metropolitan areas in the United States. AIDS 11, 325-332.

Honda M, Kitamura K, Mizutani Y, Oishi M, Arai N \& Okura T (1990) Quantitative analysis of serum IL-6 and its correlation with increased levels of serum IL-2R in HIV-induced diseases. Journal of Immunology 145, 4059-4064.

Humphrey JH, Quinn T, Fine D, Lederman H, Yamini-Roodsari S, Wu LSF, Moeller S \& Ruff AJ (1999) Short-term effects of large-dose Vitamin A Supplementation on viral load and immune response in HIV-infected women. Journal of the Acquired Immune Deficiency Syndromes and Human Retrovirology 20, 44-51.

Hussey GD, Hughes J, Potgieter S, Kessow G, Burgess J, Beatty D, Keraan M \& Carelse E (1996) Vitamin A Status and Supplementation and its Effects on Immunity in Children with AIDS. Abstracts of the XVII IVACG Meeting (Guatemala City), pp. 6. Washington, DC: International Life Science Institute, Human Nutrition Institute.

James WPT, Ferro-Luzzi A \& Waterlow JC (1988) Definition of chronic energy deficiency in adults. European Journal of Clinical Nutrition 42, 969-981.

Joint United Nations Programme on HIV/AIDS (UNAIDS) (2002) Report on the Global HIV/AIDS Epidemic. Barcelona: UNAIDS.

Kafwembe EM, Kelly P \& Ngalande P (2001) Vitamin A levels in HIV/AIDS. East African Medical Journal 78, 451-453.

Kelly P, Musonda R, Kafwembe E, Kaetano L, Keane E \& Farthing M (1999) Micronutrient supplementation in the AIDS diarrhoea-wasting syndrome in Zambia: A randomized controlled trial. AIDS 134, 495-500.

Koch J, Neal EA, Schlott MJ, Garcia-Shelton YL, Chan MF, Weaver KE \& Cello JP (1996) Zinc levels and infections in hospitalized patients with AIDS. Nutrition 12, 515-518.

Louw JA, Werbeck A, Louw ME, Kotze T, Cooper R \& Labadarios D (1992) Blood vitamin concentrations during the acute-phase response. Critical Care Medicine 20, 934-941.

Martin DJ, Blackburn NK, O'Connell KF, Brant ET \& Goetsch EA (1995a) Evaluation of the World Health Organization antibody-testing strategy for the individual patient diagnosis of HIV infection (strategy III). South African Medical Journal 85, 877-880.

Martin DJ, Sim GM, Sole GJ, Rymer L, Shalekoff S, van Niekerk ABN, Becker P, Weilbach CN, Iwanik J, Keddy K, Miller GB, Ozbay B, Ryan A, Viscovic T \& Woolf M (1995b) CD4 lymphocyte count in African patients co-infected with HIV and tuberculosis. Journal of the Acquired Immune Deficiency Syndromes and Human Retrovirology 8, 386-391.
Mejiia LA \& Chew F (1988) Hematologic effect of supplementing anemic children with vitamin A alone or in combination with iron. American Journal of Clinical Nutrition 48, 595-600.

Melchior J, Niyongabo T, Henzel D, Durack-Brown I, Henri S \& Boulier A (1999) Malnutrition and wasting, immunodepression and chronic inflammation as independent predictors of survival in HIV-infected patients. Nutrition 15, 865-869.

Mocchegiani E, Veccia S, Ancarani F, Scalise G \& Fabris N (1995) Benefit of oral zinc supplementation as an adjunct to Zidovudine (AZT) therapy against opportunistic infections in AIDS. International Journal of Immunopharmacology 17, 719-727.

Moodley D, Moodley J, Coutsoudis A, Coovadia HM \& Gouws E (1998) Vitamin A levels in normal and HIV-infected pregnant women. South African Medical Journal 88, 1029-1032.

Nuget J \& Clark S (1985) Retinoids, Differentiation and Disease. London: Pitman Publishing.

Pilch SM (1987) Analysis of vitamin A data from the health and nutrition examination surveys. Journal of Nutrition 117, 636-640.

Piwoz EG \& Preble EA (2000) A Review of the Literature and Recommendations for Nutritional Care and Support in Sub-Saharan Africa. Support for Analysis and Research in Africa (SARA) Project. Washington, DC: United States Agency for International Development (USAID), Academy for Educational Development.

Post FA, Wood R \& Maartens G (1996) CD4 and total lymphocyte counts as predictors of HIV disease progression. Quarterly Journal of Medicine 89, 505-508.

Raynes JG (1994) Carbohydrate binding proteins and immune responses. Biochemical Society Transactions 22, 69-74.

Rwangabwoba JM, Fischman H \& Semba RD (1998) Serum vitamin A levels during tuberculosis and human immunodeficiency virus infection. International Journal of Tuberculosis and Lung Disease 2, 771-773.

Semba RD (1994) Vitamin A immunity and infection. Clinical Infectious Diseases 19, 489-499.

Semba RD (1997) Vitamin A and human immunodeficiency virus infection. Proceedings of the Nutrition Society 56, 459-469.

Semba RD, Caiffa WT, Graham NMH, Cohn S \& Vlahov D (1995) Vitamin A deficiency and wasting as predictors of mortality in human immunodeficiency virus-infected injection drug users. Journal of Infectious Diseases 171, 1196-1202.

Semba RD, Graham NMH, Caiaffa WT, Margolick JB, Clement L \& Vlahov D (1993) Increased mortality associated with vitamin A deficiency during human immunodeficiency virus type 1 infection. Archives of Internal Medicine 153, 2149-2154.

Semba RD, Lyles CM, Margolick JB, Caiaffa WT, Farzadegan H, Cohn S \& Vlahov D (1998) Vitamin A supplementation and human immunodeficiency virus load in injection drug users. Journal of Infectious Diseases 177, 611-616.

Semba RD, Miotti P, Chiphangwe JD, Henderson R, Dallabettta G, Yang LP \& Hoover DR (1997a) Maternal vitamin A deficiency and child growth failure during human immunodeficiency virus infection. Journal of the Acquired Immune Deficiency Syndromes and Human Retrovirology 14, 219-222.

Semba RD, Miotti PG, Chiphangwe JD, Saah AJ, Canner JK, Dallabetta GA \& Hoover DR (1994) Maternal vitamin A deficiency and mother-to-child transmission of HIV-1. Lancet 343, 1593-1597.

Semba RD, Miotti PG \& Taha TE (1997b) Maternal Vitamin A Supplementation and Mother-to-Child Transmission of HIV Abstracts of the XVIII IVACG Meeting (Cairo). Washington, DC: International Life Science Institute, Human Nutrition Institute.

Semba RD, Muhilal \& West KP Jr (1992) Impact of vitamin A supplementation on hematological indicators of iron 
metabolism and protein status in children. Nutrition Research 12, 469-478.

Semba RD \& Tang AM (1999) Micronutrients and the pathogenesis of human immunodeficiency virus infection. British Journal of Nutrition 81, 181-189.

Shankar AH \& Prasad AS (1998) Zinc and immune function: the biological basis of altered resistance to infection. American Journal of Clinical Nutrition 68, Suppl., 447S-463S.

Stephenson CB, Alvarez JO, Kohatsu J, Hardmeier R, Kennedy JI \& Gammon RB (1994) Vitamin A is excreted in the urine during acute infection. American Journal of Clinical Nutrition 60, 388-392.

Tang AM, Graham NMH, Semba RD \& Saah AJ (1997) Association between vitamin $\mathrm{A}$ and $\mathrm{E}$ levels and HIV-1 disease progression. AIDS 11, 613-620.

Tietzman NW (1987) Fundamentals of Clinical Chemistry, 3rd ed, Philadelphia, PA: WB Saunders.
Underwood B (1990a) Methods for assessment of vitamin A status. Journal of Nutrition 120, 1459-1463.

Underwood B (1990b) Biochemical and histological methodologies for assessing Vitamin A status in human populations. Methods in Enzymology 190, 242-251.

World Health Organization International Collaborating Group for the Study of the World Health Organization Staging System (1993) Proposed "World Health Organization Staging System for HIV Infection and Disease": preliminary testing by an international collaborative cross-sectional study. AIDS 7, 711-718.

Young B, Gleeson M \& Cripps AW (1991) C-Reactive Protein: A critical review. Pathology 23, 118-124.

Zinc Investigators' Collaborative Group (1999) Prevention of diarrhoea and pneumonia by zinc supplementation in children from developing countries: Pooled analysis of randomised controlled trials. Journal of Pediatrics 135, 689-697. 